\title{
Does catch-and-release angling pose a threat to American eel? A hooking mortality experiment
}

\author{
M. Aline Litt $^{1,2, *}$, Brooke S. Etherington ${ }^{1}$, Lee F. G. Gutowsky ${ }^{3}$, \\ Nicolas W. R. Lapointe ${ }^{2}$, Steven J. Cooke ${ }^{1}$ \\ ${ }^{1}$ Fish Ecology and Conservation Physiology Laboratory, Department of Biology, Carleton University, Ottawa, ON, K1S 5B6, \\ Canada \\ ${ }^{2}$ Canadian Wildlife Federation, Kanata, ON, K2M 2W1, Canada \\ ${ }^{3}$ Aquatic Research and Monitoring Section, Ontario Ministry of Natural Resources and Forestry, Peterborough, ON, K9L 1Z8, \\ Canada
}

\begin{abstract}
Incidental capture of protected fishes usually calls for immediate release, however, post-release survival has not been investigated for many protected species. The American eel Anguilla rostrata is an example of an imperiled species that is incidentally captured by recreational anglers, but for which the impacts of catch and release are unknown. In this study, we examined the short-term ( $7 \mathrm{~d}$ ) mortality and injury of American eels $(\mathrm{n}=207)$ following simulated catch-and-release scenarios (involving manually embedded hooks) in a controlled experiment. Specifically, we compared the effects of cutting the line versus removing the hook, as well as shallow versus deep hooking, in holding tanks. No mortalities occurred in any of the groups during a $7 \mathrm{~d}$ monitoring period, and most eels exhibited little to mild injury. A high degree of hook shedding occurred in groups where the hook was shallowly embedded. Hooking depth was significantly related to hook-shedding rate, with $93.7 \%$ of hooks shed in the shallow-hook-line-cut group compared to $71.8 \%$ of hooks shed in the deep-hook-line-cut group. Our results suggest that recreationally captured American eels may be relatively resilient to catch and release, but validation of these results in a field setting is recommended.
\end{abstract}

KEY WORDS: Recreational fishing $\cdot$ Line cutting $\cdot$ Hooking mortality $\cdot$ American eel $\cdot$ Conservation · Anguilla rostrata

\section{INTRODUCTION}

Recreational fishing is a popular activity, with estimates of 220 million (World Bank 2012) to 700 million (Cooke \& Cowx 2004) people participating on a global scale. Despite the prevalence of recreational fishing, its implications for the management of fish stocks may be entirely overlooked (Post et al. 2002) or assumed to be minimal compared to the effects of commercial fishing (Cooke \& Cowx 2004, 2006, Lewin et al. 2006). This is particularly true for recreational catch-and-release angling because if a fish is not harvested, it is as-

${ }^{*}$ Corresponding author: littaline@gmail.com sumed to survive the angling interaction (Muoneke \& Childress 1994, Cooke \& Schramm 2007); however, several hundred catch-and-release studies have revealed that the survival of fish following catch and release is highly variable among species and contexts (Muoneke \& Childress 1994, Bartholomew \& Bohnsack 2005, Cooke \& Wilde 2007), and that even when a fish survives, significant sub-lethal impairments (e.g. behavioural, physiological) can occur (Davie \& Kopf 2006, Arlinghaus et al. 2007).

Catch-and-release research has identified a wide range of variables influencing survival and fitness of

(C) The authors 2020. Open Access under Creative Commons by Attribution Licence. Use, distribution and reproduction are unrestricted. Authors and original publication must be credited. 
released fishes (for a full review, see Brownscombe et al. 2017). Hooking location is considered a key factor in determining the outcome of released fishes, with deep hooking (defined for the purpose of this study as the base of the tongue or deeper) being a predominant cause of post-release mortality (Muoneke \& Childress 1994, Bartholomew \& Bohnsack 2005, Cooke \& Wilde 2007). For many species, cutting the line rather than removing the hook increases survival of deeply hooked fish (Tsuboi et al. 2006, Butcher et al. 2007, Fobert et al. 2009, Grixti et al. 2010). For example, hook removal attempts for deeply hooked European eels Anguilla anguilla resulted in higher mortality $(64.4 \%)$ compared to line cutting $(25.1 \%$ mortality) (Weltersbach et al. 2018). Line cutting is effective because it prevents further injury associated with fish struggling during hook removal, but it also reduces the length of air exposure, another key factor influencing survival in catch-and-release angling. Air exposure has various lethal and sublethal effects on a variety of fish species (Ferguson \& Tufts 1992, Arlinghaus \& Hallermann 2007), and catch-and-release principles recommend limiting air exposure as much as possible (Pelletier et al. 2007, Cook et al. 2015).

Much of the catch-and-release research to date has focussed on the most popular game fish species (Cooke \& Suski 2005), with comparatively less research on rare or imperiled species. Although fisheries closures are generally implemented to protect imperiled species from targeted angling and harvesting, it is often impossible to avoid their incidental capture as bycatch when anglers are targeting other species. To understand the effects of these events on imperiled species, it is crucial to conduct at minimum a rapid assessment evaluating the species' resilience to catch-and-release practices (Bower et al. 2016, Cooke et al. 2016).

Catch-and-release risk has not been assessed for the American eel A. rostrata. This catadromous fish has exhibited drastic declines in recruitment in many parts of its range (Castonguay et al. 1994, Casselman 2003). The American eel is listed as Endangered on the IUCN red list (Jacoby et al. 2017), as well as in Ontario (Canada), where recruitment has declined by more than $99 \%$ since the early 1980s (Casselman 2003, MacGregor et al. 2013). In Ontario, the Upper St. Lawrence-Lake Ontario river system and the Ottawa river system both contain American eels. The eels in these drainage systems are almost exclusively females, with a larger body size and higher fecundity than elsewhere in the species' range (Castonguay et al.
1994, Casselman 2003). Consequently, it is believed that these females are significant contributors to the spawning biomass for the entire species, and their decline is of concern for conservation.

The potential effects of incidental capture via recreational fishing on American eels are not considered in the Ontario Recovery Strategy for the species (MacGregor et al. 2013). Under the Ontario Endangered Species Act of 2007 (www.ontario.ca/laws/statute/ 07e06), all fishing for eels are prohibited, and any incidentally captured eels must be released. However, there are anecdotal reports of angler discomfort with the handling of eels, leading some anglers to cut the line rather than remove the hook. The sub-lethal and lethal effects on American eels from cutting the line rather than removing the hook, as well as from catch and release in general, remain unknown. The objective of this study was to evaluate risk posed by catchand-release angling to American eels. We used a controlled experiment to quantify injury and mortality of eels following simulated catch-and-release scenarios (cutting the line and removing the hook). This experiment was instigated by anecdotal reports in Ontario, and the findings are of primary importance for Ontario management of eels (where current declines indicate a particularly dire situation for the species). However, due to the low abundance of eels and capture restrictions for the species in Ontario, eels from New Brunswick (NB) were used as a substitute. For this investigation, we tested the null hypothesis that catch and release of eels does not cause post-release mortality from injuries sustained during hook removal. We predicted that hook removal would cause higher mortality rates than cutting the fishing line. This prediction is based on the wealth of catch-andrelease research on other species, which indicates that line cutting reduces mortality, especially for deeply hooked fish.

\section{MATERIALS AND METHODS}

We obtained 207 American eels (30-81 cm total length, 128-530 g; Table 1) from a commercial fyke net fishery in French Lake, NB, Canada $\left(45^{\circ} 55^{\prime} \mathrm{N}\right.$, $66^{\circ} 17^{\prime} \mathrm{W}$ ) in June 2018 and transported to Mactaquac Biodiversity Facility, NB, in an aerated tank. At the facility, eels were held in 4 holding tanks $(91 \times 457 \times 46$ $\mathrm{cm}$ ) with gravel substrate and short lengths of pipes for shelter. Holding tanks were supplied with flowthrough water from the St. John River at ambient temperature (mean $\pm \mathrm{SD}=13.7 \pm 1.66^{\circ} \mathrm{C}$ ) and ambient dissolved oxygen levels $\left(10.6 \pm 0.74 \mathrm{mg} \mathrm{l}^{-1}\right)$. 
Table 1. Sample size and means $( \pm \mathrm{SD})$ of total length and mass, and handling time for the control group, sham group and 4 groups by hook depth (shallow or deep) and treatment (hook-removal or line-cut). These measurements were all taken post-euthanasia. NA: not applicable (these groups did not undergo the catch-and-release treatments of line cut or hook removal)

\begin{tabular}{|lcccc|}
\hline Group & $\mathrm{n}$ & $\begin{array}{c}\text { Total length } \\
(\mathrm{cm})\end{array}$ & $\begin{array}{c}\text { Mass } \\
(\mathrm{g})\end{array}$ & $\begin{array}{c}\text { Handling } \\
\text { time }(\mathrm{s})\end{array}$ \\
\hline Control & 48 & $50.3 \pm 6.4$ & $235.0 \pm 101.9$ & $\mathrm{NA}$ \\
Sham & 32 & $55.1 \pm 6.1$ & $287.0 \pm 112.9$ & $\mathrm{NA}$ \\
Deep-hook-line-cut & 32 & $53.7 \pm 6.5$ & $263.5 \pm 109.9$ & $31.6 \pm 18.3$ \\
Deep-hook-hook-removed & 31 & $54.7 \pm 7.1$ & $271.2 \pm 93.9$ & $96.6 \pm 86.5$ \\
Shallow-hook-line-cut & 32 & $53.8 \pm 5.8$ & $256.3 \pm 96.2$ & $30.7 \pm 13.8$ \\
Shallow-hook-hook-removed & 32 & $51.4 \pm 5.5$ & $225.2 \pm 83.8$ & $47.5 \pm 34.1$ \\
\hline
\end{tabular}

After a $24 \mathrm{~h}$ holding period, eels were netted and randomly assigned to 1 of 4 groups (Fig. 1). (1) Control group eels were transferred directly to the holding tanks with minimal air exposure. Non-control groups (i.e. sham and experimental groups) were anaesthetized using clove oil (200 ppm), tagged with anchor tags, and measured for total length and weight. (2) Sham group eels were then transferred to recovery tanks. (3) Shallow-hooked eels were hooked in the lips or jaw, and (4) deep-hooked eels were hooked in the throat at the base of the tongue using pliers. All hooks were size 2 offset baitholder style with a turned down eye and barbed shank and hook, and were pre-tied to lengths of monofilament fishing line $(60-100 \mathrm{~cm})$. The hooking process was always conducted by the same individual. Anaesthetized eels were individually held in 251 recovery tanks for at least $20 \mathrm{~min}$ and until they recovered

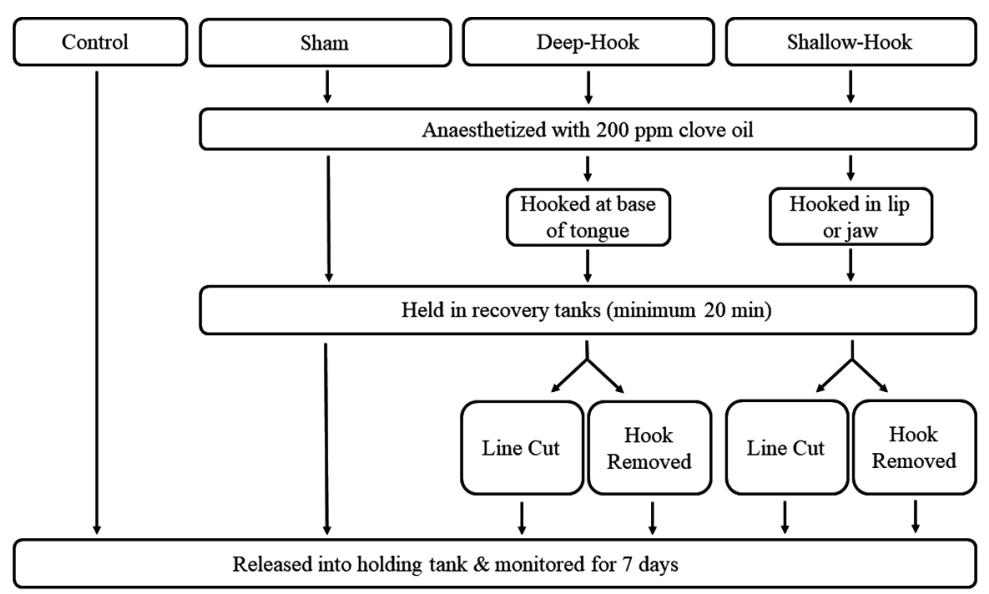

Fig. 1. Schematic of the experimental protocol. The top row indicates group names. Note that the deep-hooked and shallow-hooked eels were subdivided into line-cut and hook-removal treatments, resulting in 6 final groups: control; sham; deep-hook-line-cut; deep-hook-hook-removal; shallow-hook-line-cut; shallow-hook-hook-removal equilibrium and resumed normal swimming behaviour. During recovery, the fishing line was dragging in the water, thereby not restricting eel movement. Anaesthesia and simulated hooking were necessary for this experiment because the eels would not feed in captivity, so a true angling event was not possible. The control group allowed the confounding effects of tagging to be distinguished from the effects of the experimental treatments, while the sham group functioned in the same way for any confounding effects of anaesthesia.

After at least $20 \mathrm{~min}$ and when regular activity resumed, sham eels were released into the holding tanks. Shallow-hooked and deep-hooked eels were randomly assigned to 2 simulated catch-and-release treatments: line cut or hook removal. For both scenarios, the eel was removed from the recovery tank by the line, and handling time was measured from when the eel was lifted by the line until it was placed in the holding tank. The line-cut treatment involved using a pair of scissors to cut the line within $4 \mathrm{~cm}$ of the hook's eye. The hook-removal treatment required the mock angler to remove the hook from the eel, regardless of handling time or number of times the fish was dropped. Two mock anglers alternately attempted hook removal. Mock anglers could use a pair of fisherman's longnose hemostats to assist with hook removal, but no other equipment was used to handle or remove hooks. Generally, mock anglers tended to try removing the hook without the hemostats, but would try using the hemostats if hook removal proved challenging or time-consuming. Once the catch-and-release scenario was complete, eels were released into the holding tanks. Each of 3 holding tanks contained a random combination of eels from each treatment, but all eels in a given tank were manipulated on the same day. All eels were monitored for $7 \mathrm{~d}$ post-processing with tank checks every $24 \mathrm{~h}$ for mortalities.

After $7 \mathrm{~d}$, eels were euthanized (a requirement of the scientific permit for biosecurity reasons). All previously hooked eels were examined for injury at the hooking site. Injuries were classified into 4 levels: (0) no sign of injury, (1) a slight tear/scar but no blood, (2) a small amount of blood but no swelling, and (3) significant blood, 
clot, or swelling. All line-cut eels were checked for hook retention. If the hook was not visible at the hooking site, the eel was dissected to confirm whether it was ingested. Post-euthanasia length and weight measurements were taken for all fish (including control group fish which had not been previously weighed).

Analyses were conducted using RStudio version 1.1.383 (R Studio Team 2014) running R version 3.5.2 (R Core Team 2017). A Pearson's chi-squared test, with a Monte Carlo simulation due to small sample size, was used to examine the effect of experimental group on injury score. A Pearson's chi-squared test was used to investigate the effect of hook depth on hook shedding. A Kruskal Wallis (KW) rank-sum test was used to examine the effect of experimental group (i.e. not including control or sham groups) on handling time. In this case, the KW test was used due to highly different variances in handling time among groups. Dunn's test was used to conduct multiple comparisons. The p-values for all tests involving experimental group as a dependent variable were adjusted using a Holm's correction for multiple comparisons.

\section{RESULTS}

There were no mortalities in any of the groups over the $7 \mathrm{~d}$ holding period (see Table 1 for group sample sizes). Following euthanasia, eel necropsies revealed only minor scarring or no sign of meaningful injury in $87.4 \%$ of fish, and there was no evidence to suggest an impact of treatment on injury score $\left(\chi^{2}=5.2, \mathrm{p}>\right.$ 0.05). After the $7 \mathrm{~d}$ holding period, $82.8 \%$ of the eels in the line-cut groups had shed the hook. There was evidence of an effect of hook depth on hook shedding $\left(\chi^{2}=4.0, \mathrm{df}=1, \mathrm{p}<0.05\right)$, whereby fish hooked in more shallow locations had a greater tendency $(93.7 \%)$ to shed hooks than those hooked in deep locations $(71.8 \%)$. No ingested hooks were found during the dissections of the line-cut eels with missing hooks. There was a significant difference in handling time among experimental groups $\left(\chi^{2}=24.9, \mathrm{df}=\right.$ $3, p<0.05)$. Multiple comparisons indicated that handling the deep-hook-hook-removal group took significantly longer than handling any of the other groups (Table 1).

\section{DISCUSSION}

Our laboratory research provided little preliminary evidence to suggest that catch-and-release angling poses a significant threat to American eels over the short-term following an angling interaction. No mortalities occurred during the catch-and-release experiment, and the injury score did not suggest a difference in outcome between cutting the line and removing the hook. Additionally, $82.8 \%$ of the linecut eels shed their hooks within $7 \mathrm{~d}$. Based on our results, either method of releasing eels (cutting the line or removing the hook) is acceptable in terms of mortality outcomes. Although the research took place in New Brunswick, the results are of primary relevance to Ontario, where the release of incidentally captured eels is mandatory under the Endangered Species Act. However, the findings are also relevant for anglers elsewhere who are releasing eels as bycatch.

This is the first study to examine the effects of catch and release on American eels. We originally predicted higher mortality and increased injury in hookremoval groups because we anticipated extended handling times (and therefore increased air exposure). Hook removal did indeed take longer (72 s) than cutting the line (31 s), for both shallow- and deep-hook fish, but handling time was only statistically significantly longer for deep-hook fish. However, this did not translate to a difference in shortterm mortality or injury. This is not overly surprising because it has previously been shown that American eels exhibit a high tolerance to prolonged air exposure and hypoxemia (Hyde et al. 1987). Furthermore, our $0 \%$ mortality rate is consistent with the shortterm $(\leq 72 \mathrm{~h})$ mortality that Weltersbach et al. (2018) found for European eels (the most closely related species to American eels) that had been hooked in the lips, jaws, or oral cavity with a similar hook (size 1 J-hook). Weltersbach et al. (2018) found longerterm (43-64 d) adjusted mortality for the same treatment (hook-removed) to be $8.4 \%$. This suggests that some mortality may have been observed in our study if the holding period had been extended beyond $7 \mathrm{~d}$.

In this study, deep hooking refers to the base of the tongue. While this is consistent with some catch-andrelease research (Siewert \& Cave 1990, Meka 2004), other studies employ more extreme definitions of deep hooking, including fish hooked in the gills, gastrointestinal tract, or oesophagus (Fobert et al. 2009, Pullen et al. 2017, Weltersbach et al. 2018). Here we used a less extreme definition because we wanted to examine differences between line cutting and hook removal. Moreover, Weltersbach et al. (2018) found that hook removal was not possible in $90.9 \%$ of European eels hooked in the gills or gastrointestinal tract by a large hook. The same study found that $34.2 \%$ of European eels angled using large J-hooks (in true 
fishing events) were hooked in the gills or gastrointestinal track. Our definition of deep hooking enabled comparison of the 2 treatments (line-cut and hook-removal), but does not fully address a portion of angling scenarios in which eels swallow the hook. Future work exploring the effects of other deephooking locations (e.g. gills, oesophagus, gastrointestinal tract) is required to capture all relevant catch-and-release scenarios.

Our results revealed a high level $(82.8 \%)$ of hook shedding within $7 \mathrm{~d}$ following release. The high amount of short-term hook shedding is consistent with findings in other species $(71.4 \%$ over $10 \mathrm{~d}$ in bluegill sunfish Lepomis macrochirus, Fobert et al. 2009; $46 \%$ over 14 d in bonefish Albula vulpes, Stein et al. 2012). In European eels, hook shedding rates ranged from $0-41.2 \%$ depending on hook size, although these percentages are for eels hooked in the gills or gastrointestinal tract (Weltersbach et al. 2016 , 2018). The higher level of hook shedding in our experiment compared to the European eel studies is presumably partly attributable to the shallower placement of hooks, as is the finding of a $0 \%$ ingestion rate (although the latter may also be affected by the fact that the eels were not feeding during the holding period). Indeed, the present work did identify some evidence to suggest that hook depth impacts hook shedding ability.

The design of our experiment has some inherent limitations. A small-scale, laboratory approach was chosen in order to obtain a higher level of control (compared to the variability in a field study) because this experiment was uncovering initial knowledge about the effects of recreational fishing on American eels. The behaviour and physiological response of the eels may have been altered due to artificial elements such as the holding tanks and manual hook embedding (Cooke et al. 2013). Further work in a field setting is required to validate the present findings. Furthermore, anaesthetizing and tagging the eels may have altered the results of the study, although the study was designed to reduce the impact of confounding variables. The sham group was anaesthetized so that any lethal effect from chemical anaesthesia would be distinct from the effect of our experimental treatments, and none was observed. To account for the effects of tagging, the control group was held in the same artificial environment without being handled or anchor tagged. Even with these design considerations, the scope of this study was not exhaustive, in terms of fully answering the research question. This topic would benefit from future research examining additional predictor vari- ables (e.g. different hook types), more extreme predictor variables (e.g. deeper hooking) and other potential sub-lethal effects of catch-and-release on eels (e.g. impairment of feeding, changes in behaviour). Our findings contribute to a growing body of literature regarding the conservation of American eels by addressing the previously overlooked possibility of a threat from recreational catch-and-release angling. Future research is recommended to further evaluate the topic, including the undertaking of field studies to verify these results in non-simulated scenarios. Our research preliminarily suggests that incidental capture by anglers does not pose a major threat to American eels if released, whether following hook removal or line cutting.

Acknowledgements. This work was funded by the Canadian Wildlife Federation. We are grateful to Cormier Fisheries and the staff of Fisheries and Oceans Canada's Mactaquac Biodiversity Facility for their assistance. S.J.C. is further supported by NSERC and the Canada Research Chairs Program. Additional support was provided by Project Learning Tree. This research was conducted in accordance with guidelines from the Canadian Council on Animal Care at Carleton University and under a New Brunswick Introductions and Transfers license (NB 2018-034) granted by the Department of Fisheries and Oceans.

\section{LITERATURE CITED}

Arlinghaus R, Hallermann J (2007) Effects of air exposure on mortality and growth of undersized pikeperch, Sander lucioperca, at low water temperatures with implications for catch-and-release fishing. Fish Manag Ecol 14:155-160

* Arlinghaus R, Cooke SJ, Lyman J, Policansky D and others (2007) Understanding the complexity of catch-and-release in recreational fishing: an integrative synthesis of global knowledge from historical, ethical, social, and biological perspectives. Rev Fish Sci 15:75-167

* Bartholomew A, Bohnsack JA (2005) A review of catch-andrelease angling mortality with implications for no-take reserves. Rev Fish Biol Fish 15:129-154

* Bower SD, Danylchuk AJ, Raghavan R, Clark-Danylchuk SE, Pinder AC, Cooke SJ (2016) Rapid assessment of the physiological impacts caused by catch-and-release angling on blue-finned mahseer (Tor sp.) of the Cauvery River, India. Fish Manag Ecol 23:208-217

Brownscombe JW, Danylchuk AJ, Chapman JM, Gutowsky LFG, Cooke SJ (2017) Best practices for catch-and-release recreational fisheries-angling tools and tactics. Fish Res 186:693-705

Butcher PA, Broadhurst MK, Reynolds D, Reid DD, Gray CA (2007) Release method and anatomical hook location: effects on short-term mortality of angler-caught Acanthopagrus australis and Argyrosomus japonicus. Dis Aquat Org 74:17-26

Casselman JM (2003) Dynamics of resources of the American eel, Anguilla rostrata: declining abundance in the 1990s. In: Aida K, Tsukamoto K, Yamauchi K (eds) Eel biology. Springer, Tokyo, p 255-274 
Castonguay M, Hodson PV, Couillard CM, Eckersley MJ, Dutil JD, Verreault G (1994) Why is recruitment of the American eel, Anguilla rostrata, declining in the St. Lawrence River and Gulf? Can J Fish Aquat Sci 51: 479-488

Cook KV, Lennox RJ, Hinch SG, Cooke SJ (2015) Fish out of water: How much air is too much? Fisheries 40:452-461

* Cooke SJ, Cowx IG (2004) The role of recreational fishing in global fish crises. Bioscience 54:857-859

Cooke SJ, Cowx IG (2006) Contrasting recreational and commercial fishing: searching for common issues to promote unified conservation of fisheries resources and aquatic environments. Biol Conserv 128:93-108

Cooke SJ, Schramm HL (2007) Catch-and-release science and its application to conservation and management of recreational fisheries. Fish Manag Ecol 14:73-79

Cooke SJ, Suski CD (2005) Do we need species-specific guidelines for catch-and-release recreational angling to effectively conserve diverse fishery resources? Biodivers Conserv 14:1195-1209

Cooke SJ, Wilde GR (2007) The fate of fish released by recreational anglers. In: Kennelly SJ (ed) By-catch reduction in the world's fisheries. Springer Netherlands, Dordrecht, p 181-234

Cooke SJ, Donaldson MR, O'Connor CM, Raby GD and others (2013) The physiological consequences of catch-andrelease angling: perspectives on experimental design, interpretation, extrapolation, and relevance to stakeholders. Fish Manag Ecol 20:268-287

Cooke SJ, Hogan ZS, Butcher PA, Stokesbury MJW and others (2016) Angling for endangered fish: conservation problem or conservation action? Fish Fish 17:249-265

Davie PS, Kopf RK (2006) Physiology, behaviour and welfare of fish during recreational fishing and after release. $\mathrm{N} \mathrm{Z}$ Vet J 54:161-172

Ferguson RA, Tufts BL (1992) Physiological effects of brief air exposure in exhaustively exercised rainbow trout (Oncorhynchus mykiss): implications for 'catch and release' fisheries. Can J Fish Aquat Sci 49:1157-1162

Fobert E, Meining P, Colotelo A, O'Connor C, Cooke SJ (2009) Cut the line or remove the hook? An evaluation of sublethal and lethal endpoints for deeply hooked bluegill. Fish Res 99:38-46

Grixti D, Conron SD, Morison A (2010) Post-release survival of recreationally caught snapper, Pagrus auratus, in Port Phillip Bay, south-eastern Australia. Fish Manag Ecol 17: 1-9

Hyde DA, Moon TW, Perry SF (1987) Physiological consequences of prolonged aerial exposure in the American eel, Anguilla rostrata: blood respiratory and acid-base status. J Comp Physiol B 157:635-642

Jacoby D, Casselman J, DeLucia M, Gollock M (2017) Anguilla rostrata. The IUCN red list of threatened spe-

Editorial responsibility: Austin Gallagher,

Herndon, Virginia, USA cies 2017. e.T191108A121739077. https://www.iucnredlist. org/species/191108/121739077

Lewin WC, Arlinghaus R, Mehner T (2006) Documented and potential biological impacts of recreational fishing: insights for management and conservation. Rev Fish Sci 14:305-367

MacGregor R, Casselman J, Greig L, Dettmers J, Allen WA, McDermott L, Haxton T (2013) American eel (Anguilla rostrata) in Ontario. Ontario Ministry of Natural Resources, Peterborough

Meka JM (2004) The influence of hook type, angler experience, and fish size on injury rates and the duration of capture in an Alaskan catch-and-release rainbow trout fishery. N Am J Fish Manag 24:1309-1321

Muoneke MI, Childress MW (1994) Hooking mortality: a review for recreational fisheries. Rev Fish Sci 2: 123-156

* Pelletier C, Hanson KC, Cooke SJ (2007) Do catch-and-release guidelines from state and provincial fisheries agencies in North America conform to scientifically based best practices? Environ Manag 39:760-773

Post JR, Sullivan M, Cox S, Lester NP and others (2002) Canada's recreational fisheries: The invisible collapse? Fisheries 27:6-17

* Pullen CE, Hayes K, O'Connor CM, Arlinghaus R, Suski CD, Midwood JD, Cooke SJ (2017) Consequences of oral lure retention on the physiology and behaviour of adult northern pike (Esox lucius L.). Fish Res 186:601-611

R Core Team (2017) R: a language and environment for statistical computing. R Foundation for Statistical Computing, Vienna

R Studio Team (2014) RStudio: integrated development for R. RStudio, Boston, MA

* Siewert HF, Cave JB (1990) Survival of released bluegill, Lepomis macrochirus, caught on artificial flies, worms, and spinner lures. J Freshw Ecol 5:407-411

* Stein JA, Shultz AD, Cooke SJ, Danylchuk AJ, Hayward K, Suski CD (2012) The influence of hook size, type, and location on hook retention and survival of angled bonefish (Albula vulpes). Fish Res 113:147-152

Tsuboi J, Morita K, Ikeda H (2006) Fate of deep-hooked white-spotted charr after cutting the line in a catch-andrelease fishery. Fish Res 79:226-230

Weltersbach MS, Ferter K, Sambraus F, Strehlow HV (2016) Hook shedding and post-release fate of deep-hooked European eel. Biol Conserv 199:16-24

W Weltersbach MS, Strehlow HV, Ferter K, Klefoth T, de Graaf M, Dorow M (2018) Estimating and mitigating postrelease mortality of European eel by combining citizen science with a catch-and-release angling experiment. Fish Res 201:98-108

World Bank (2012) Hidden harvest: the global contribution of capture fisheries. World Bank, Washington, DC

Submitted: May 24, 2019; Accepted: October 21, 2019

Proofs received from author(s): December 17, 2019 